\title{
Management practices and financial feasibility of milk production in dairy farming unit
}

\author{
SHREYA V. AMARAPURKAR AND C. MURTHY
}

Received : 04.09.2015; Revised : 26.09.2015; Accepted : 27.09.2015

\begin{abstract}
The present study was conducted in Belagavi district of Karnataka. The multistage sampling technique was followed for the selection of the farmers. In Belagavi district, Gokak and Athani taluks were selected purposively on the basis of highest dairy animal population. From each taluks top 6 milk producing villages were selected purposively, where the dairy farming was widely practiced in year 2014-15. The data were collected from 10 dairy farmers from each village, 5 dairy co-operative societies and 5 milkmen's were selected from each talukas. Thus, the total sample size is 140 . The data was summarized and analyzed with the help of statistical tools like tabular analysis and financial feasibility analysis. The study reveals that, net present value of buffalo, cross breed cow and indigenous cow was Rs. 76755.80, Rs. 102647.00 and Rs. -508.95 , respectively. Benefit cost ratio was found to be highest in cross breed cow farm (1.45), followed by buffalo farm (1.42) and indigenous cow farm (0.99). The internal rate of return is found to be highest in cross breed cow farming unit (36.31\%), followed by buffalo farming unit $(32.65 \%)$ and indigenous cow farming unit $(11.7 \%)$. It shows that the indigenous cow farms are financially not feasible in study area.
\end{abstract}

KEY WORDS : Management practices, Financial feasibility, Milk production, Dairy farming unit

How to cite this paper : Patil, Sanidev B. and Murthy, C. (2015). Management practices and financial feasibility of milk production in dairy farming unit. Internat. J. Com. \& Bus. Manage, 8(2) : 229-236.

\section{MEMBERS OF THE RESEARCH FORUM}

Correspondence to:

SHREYA V. AMARAPURKAR, Department of Agribusiness Management, College of Agriculture, University of Agricultural Sciences, DHARWAD (KARNATAKA) INDIA

\section{Authors' affiliations:}

C. MURTHY, Department of Agribusiness Management, College of Agriculture, University of Agricultural Sciences, DHARWAD (KARNATAKA) INDIA 